\title{
Temporal and Spatial Analysis of the Ecosystem Service Values in the Three Gorges Reservoir Area of China Based on Land Use Change
}

\section{Xu Zhao}

China Three Gorges University

Ping Yi ( $\nabla$ yiping@ctgu.edu.cn )

China Three Gorges University https://orcid.org/0000-0001-9398-1263

Jingjing Xia

Wuhan University

Weijun He

China Three Gorges University

Xin Gao

Shanghai Jiao Tong University

\section{Research Article}

Keywords: Land use change, Ecosystem service value, Spatial correlation, Equivalent value factor, Human activities, Three Gorges Reservoir area

Posted Date: September 3rd, 2021

DOI: https://doi.org/10.21203/rs.3.rs-760058/v1

License: (1) This work is licensed under a Creative Commons Attribution 4.0 International License.

Read Full License

Version of Record: A version of this preprint was published at Environmental Science and Pollution Research on December 2nd, 2021. See the published version at https://doi.org/10.1007/s11356-02117827-2. 
1 Temporal and spatial analysis of the ecosystem service values in 2 the Three Gorges Reservoir area of China based on land use 3 change

4

$5 \quad \mathrm{Xu} \mathrm{Zhao}{ }^{1,2} \cdot \mathrm{Ping} \mathrm{Yi}^{1} \cdot$ Jingjing Xia ${ }^{3} \cdot$ Weijun $\mathrm{He}^{1} \cdot \mathrm{Xin} \mathrm{Gao}^{4}$

61 College of Economics and Management, China Three Gorges University, Yichang 443000, China

72 Research Center for Reservoir Resettlement, China Three Gorges University, Yichang 443000,

8 China

93 China Institute of Development Strategy and Planning, Wuhan University, Wuhan 430079, China

104 Antai College of Economics and Management, Shanghai Jiao Tong University, Shanghai 200030,

11 China

*Correspondence author

E-mail: yiping@ctgu.edu.cn

Telephone: +86-18771830261

Note on preprint server:

I have not submitted my manuscript to a preprint server before submitting it to Environmental Science and Pollution Research.

Declarations

Ethics approval and consent to participate Not applicable.

Consent for publication Not applicable.

Availability of data and materials All data generated or analysed during this study are included in this published article.

Competing interests The authors declare that they have no competing interests.

Funding This research was funded by the Major Program of National Social Foundation of China (Project No. 19ZDA089)

Authors' contributions All authors contribute substantially in this research work. Xu Zhao and Ping Yi were responsible for conceptualizing the study and writing the initial draft of this manuscript. Jingjing Xia and Weijun He contributed to the editing and multiple reviews of the manuscript. Ping Yi and Xin Gao performed the data processing and analysis. All authors read and approved the final manuscript.

Acknowledgements The authors are very grateful to the many people in data collection and article review. 


\title{
Temporal and spatial analysis of the ecosystem service values in
}

\section{the Three Gorges Reservoir area of China based on land use}

\author{
change
}

\begin{abstract}
The Three Gorges Reservoir area (TGRA) has complex geological conditions and a fragile ecological environment. The construction of the Three Gorges Project triggered a series of ecological and environmental issues and social disputes, which have attracted much attention in recent years. However, it is still unclear how the temporal and spatial characteristics of ecosystem service value (ESV) in the TGRA changed in each stage of the Three Gorges Project along with the implementation of some ecological restoration projects. Based on four periods of land use data from 2000 to 2018, the changes in land use were studied and the ecosystem service values (ESVs) were estimated. Then, we analysed the spatial distribution and dynamic changes in ecosystem services. The results showed that from 2000 to 2018, grassland and construction land were the largest land use types showing area reductions and increases and the conversion of cropland to forestland, grassland and construction land represented the most important land type changes. In the past 18 years, due to the increase in forestland and water area, the ESVs increased by 2.7 billion yuan, with a growth rate of $3.46 \%$. From the perspective of contribution rate, the conversion of cropland to forestland had the largest contribution rate to the increase in ESV. The ESV was higher in the northeast and lower in the southwest, and its changes have significant positive autocorrelation in spatial distribution. The hot spots of ESV change were mainly distributed in the main stream of the Yangtze River and the reservoir area. This research provides a reference for land resource allocation and experience for the ecological environment protection and sustainable development of the Yangtze River Basin.

Keywords Land use change $\cdot$ Ecosystem service value $\cdot$ Spatial correlation $\cdot$ Equivalent value factor $•$ Human activities $•$ Three Gorges Reservoir area
\end{abstract}

\section{Introduction}

Ecosystem services refer to the benefits that humans obtain directly or indirectly from the ecosystem, including provisioning services, regulation services, supporting services and cultural services (Assessment 2005; Costanza et al. 1997). The sustainable development of the social economy depends on the sustainable supply of ecosystem services (Liu \&Wu 2021; Zhou et al. 2016). However, the advancement of social technology has greatly accelerated the plundering of natural resources by humans and destroyed the ecological environment. Humans gain economic prosperity at the expense of ecosystem services (Cao et al. 2021). Therefore, it is imperative to evaluate ecosystem service value (ESV) to alleviate the increasingly scarce ecosystem services and help people clearly recognize the important role of ecosystem services in human survival. Global scholars have been researching the value of ecosystem services for approximately 30 years. In 1997, two milestone studies were published: one by Daily (1997), which was titled "Nature's Services: Societal Dependence on Natural Ecosystems", and the other by Costanza et al. (1997), which was 
titled "The Value of the World's Ecosystem Service and Nature Capital" and published in the journal Nature. The latter paper systematically calculated the total value of ecosystem services worldwide and depicted its spatial distribution. The publication of these studies has triggered a global research boom on ecological capital and ecosystem services, which has become a frontier issue.

Land use change (LUC) is a significant way for humans to affect ecosystems (Yu et al. 2020), and LUC can change the functions and products of ecosystem services (Hasan et al. 2020; Li et al. 2021; Liang et al. 2021; Wu et al. 2018). A previous assessment (2005) pointed out that LUC has been the most important driving force leading to changes in the value of terrestrial ecosystem services since the 1950s. As an important part of human well-being, LUC and its impact on ecosystem services have received widespread attention worldwide (Fei et al. 2018; Gashaw et al. 2018; Li et al. 2021; Schirpke et al. 2020; Tan et al. 2020). Liu et al. (2020) assessed the value of ecosystem services in the Bohai Rim coastal zone and found that the decrease in saltwater wetland area and the increase in construction land area were the reasons for the decrease in ESV. Wu et al. (2020) estimated the value of ecosystem services in Jiangsu Province and proposed that rapid urbanization in the region has placed great pressure on ecosystem services. Taking Yongshou County on the Loess Plateau as an example, Zhang et al. (2020a) found that the implementation of the ecological restoration project changed the rural land use structure, greatly improved the ecological environment, and had a significant positive impact on ecosystem services. Existing studies mostly focus on the impact of a single land use type change on the value of ecosystem services (Wang et al. 2019a). However, few related studies have deeply analysed the changes in the value of ecosystem services brought about by the conversion between various land types in the process of LUC. Therefore, clarifying the impact of different land use transfer types on ESV can further reveal the impact mechanism of LUC on ESV and provide guidance for the optimization of land use.

In terms of the value estimation of ecosystem services, there are two main methods: the functional value evaluation method and the equivalent factor method. The functional value evaluation method is a common method for evaluating the characteristics of ecosystem services in small-scale regions by obtaining monitoring data from fixed point observations and combining them with related ecological models (Fu \&Zhang 2014; Zhang et al. 2020c). This method requires a large amount of data, the process is complicated, and some parameters are not easy to obtain. The most widely used value assessment method is the equivalent factor method. This method does not require complex model calculations and requires less data (Wang \&Dun 2015). On the basis of Costanza et al. (1997) and combined with the actual situation in China, Chinese scholars Xie et al. (2008) conducted a questionnaire survey of 700 professionals with ecological backgrounds in China and proposed a value equivalent table suitable for the Chinese region. This table is used by many scholars to estimate changes in the value of ecosystem services in China. Because the value assessment method easily summarizes and compares different services, it is more suitable for the comparative study of ecosystem service changes under different land use change scenarios.

The Three Gorges Reservoir area (TGRA) is a typical ecologically fragile area in China (Huang et al. 2019; Zhang et al. 2020b), and it is also an ecological barrier area of strategic significance in the Yangtze River Basin (Li et al. 2019a). As the world's largest hydroelectric project, the Three Gorges Project has affected the ecosystem of the TGRA (Yuan et al. 2013; Zheng 2016), including soil erosion (Huang et al. 2020; Xiao et al. 2020), water quality (Holbach et al. 2013; Li et al. 2019b; Xiang et al. 2021) and biodiversity (Wu et al. 2003), which has attracted widespread attention from ecologists worldwide. With the rapid economic development in the upper reaches of the Yangtze 
River and the construction and impoundment of the Three Gorges Dam, the land use pattern in the reservoir has changed greatly, and the value of ecosystem services closely related to it has also changed. Since 2000, the Chinese government has paid more attention to the ecological environment of the TGRA. Ecological projects, such as the Grain for Green Program and Natural Forest Protection Program, have been implemented successively, and a large number of other land use types have been converted to forest and grassland.

Previous studies have been conducted on the LUC in the TGRA and its impact on the ecosystem (Chu et al. 2018; Yan et al. 2014). A study showed that the LUC characteristics are different in different stages of the Three Gorges Dam construction. During the period from 1990 to 2010, water impoundment and inundation, resettlement and relocation, and urbanization led to the expansion of water area and the reduction of cropland (Shao et al. 2013). Guo andZhou (2016) estimated the total value of ecosystem services in the TGRA from 2000 to 2014 and explored the relationship between changes in land use and ecosystem services before and after the completion of water storage in the reservoir area. However, research on the specific characteristics of LUC and its ecological effects in different construction periods of the Three Gorges Project is limited. The lack of this knowledge hinders our ability to formulate the most reasonable and effective sustainable development measures for different stages.

Taking the TGRA as the research object, this paper used the equivalent factor method to calculate the value of ecosystem services in the study area and studied the impact of LUC on ecosystem services. The study aims to (1) analyse the spatiotemporal characteristics of LUC; (2) assess the temporal and spatial changes in ESV and its spatial heterogeneity; and (3) analyse the impact of LUC on ESV.

\section{Materials and methods}

\subsection{Study area}

The TGRA lies at the junction of the Sichuan Basin and the middle and lower reaches of the Yangtze River Plain, located at $105^{\circ} 50^{\prime}-111^{\circ} 65^{\prime} \mathrm{E}$ and $28^{\circ} 56^{\prime}-31^{\circ} 44^{\prime} \mathrm{N}$ (Fig. 1). Covering an area of approximately $58000 \mathrm{~km}^{2}$, it contains 26 (4 in Hubei Province and 22 in Chongqing City) districts or counties. The area is located in a subtropical humid climate, with high temperature and rain in summer and mild and humid temperatures in winter. The average annual temperature is approximately $18^{\circ} \mathrm{C}$, and the average annual precipitation is $1100 \mathrm{~mm}$. With the construction of the Three Gorges Project and socioeconomic development of the TGRA, the land use patterns have changed, which may affect ecosystem services. 


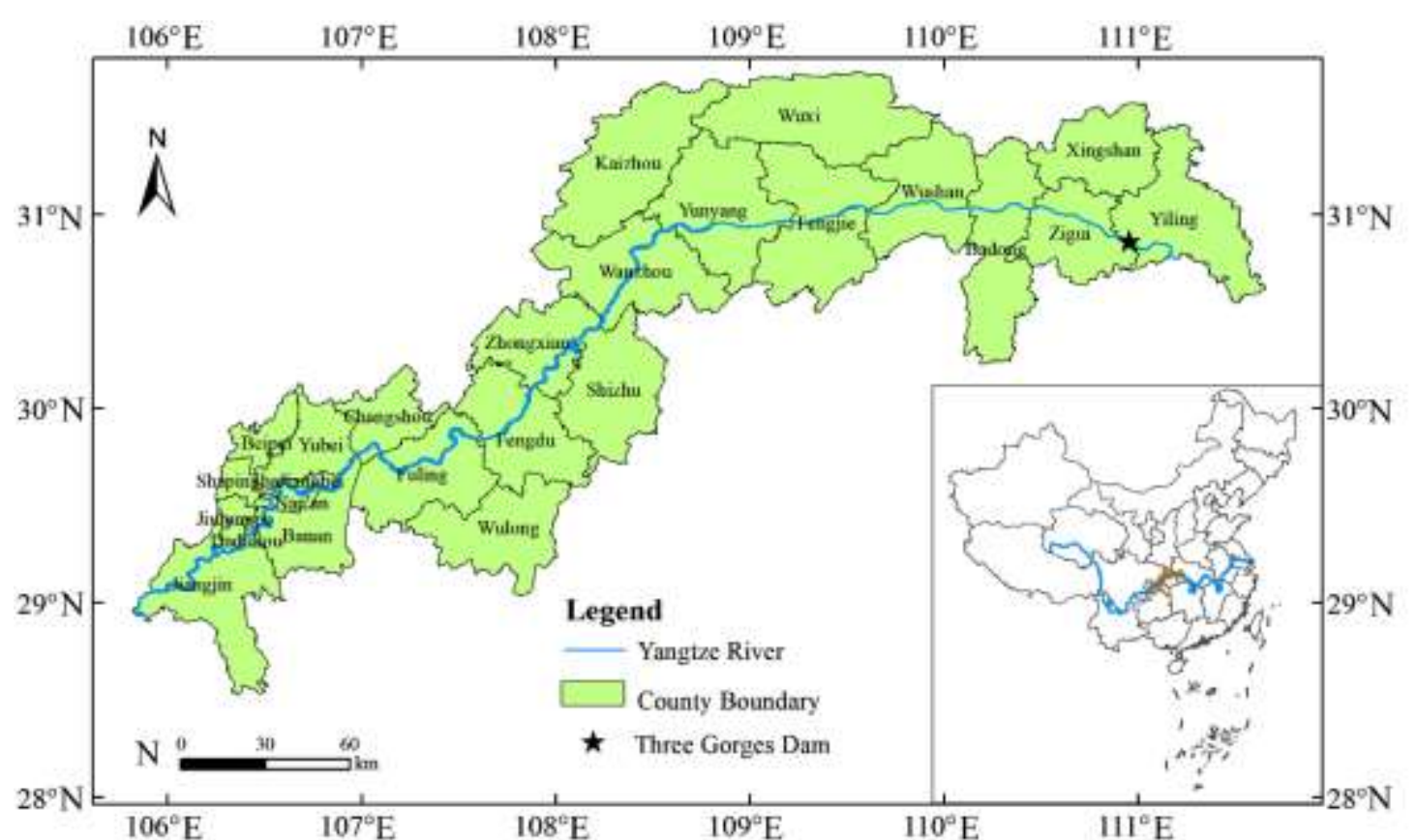

Fig. 1 Location of the Three Gorges Reservoir area

\subsection{Data sources}

The data of this study mainly include land use data, digital elevation models and socioeconomic data. The land use data with a spatial resolution of $1 \times 1 \mathrm{~km}$ in 2000, 2005, 2010 and 2018 were obtained from the Resource and Environment Data Cloud Platform of the Chinese Academy of Sciences. These data are based on Landsat- 8 remote sensing images and are generated by manual visual interpretation. The land use types were divided into cropland, forestland, grassland, water, construction land, and bare land. The socioeconomic statistics data were obtained from the Chongqing Statistical Yearbook, Yichang Statistical Yearbook, Enshi Statistical Yearbook, National Farm Product Cost-benefit Survey, and China Yearbook of Agricultural Price Survey.

\subsection{Ecosystem services valuation}

In 1997, Costanza et al. (1997) began to evaluate the value of global ecosystem services. Based on their research results and combined with the characteristics of China's ecosystem, Chinese scholars Xie et al. (2015) formulated the equivalent factor table of ESV in China. In this study, we modified the table of equivalent value factors based on the equivalent value factor table proposed by Xie et al. (2015) and the actual situation in the study area. Specifically, the equivalent value of cropland was multiplied by the corresponding equivalent value of the proportion of paddy field and dry land in the study area. The equivalent value of forestland was determined based on the average value of coniferous forest, mixed coniferous broad-leaved forest, broad-leaved forest and shrub forest. The equivalent value of grassland was determined based on the average value of shrubs and meadows. We determined that the equivalent value of the construction land was 0 according to related research. When calculating the ESV, the average grain price of the TGRA was revised according to the consumer price index (CPI) to construct an ESV coefficient suitable for the region. The ESV model was revised as follows:

$a_{i}=\frac{C P I}{100} \quad(I=0,1,2 \cdots, n)$ 
$179 \quad \frac{a_{1}}{a_{0}} \times \frac{a_{2}}{a_{1}} \times \frac{a_{3}}{a_{2}} \times \cdots \times \frac{a_{n}}{a_{n-1}}=\frac{a_{n}}{a_{0}}$

$180 \quad \mathrm{VC}=\mathrm{V} C_{0} \times \frac{a_{n}}{a_{o}}$

$181 \quad \mathrm{~V} C_{0}=\frac{1}{7} \sum_{i=1}^{n} \frac{p_{i} q_{i} m_{i}}{M}$

182 where $a_{i}$ is the unit CPI of i-year; $a_{1} / a_{0}$ is the initial chained $C P I$; VC is the unit price of

183 the $\mathrm{ESV} ; \mathrm{VC}_{0}$ is the economic value of the cropland's production services; $p_{i}$ is the average grain

184 output of the study area; $q_{i}$ is the average grain price of the study area; $m_{i}$ is the average grain

185 area of the study area; and $\mathrm{M}$ is the total grain area of the study area. According to the

186 characteristics of the study area, we selected rice, corn, soybean, and potato as the main types of

187 food crops.

188 According to the value equivalent factor table and the unit price of the ESV, we calculated the value 189 coefficient of ecosystem services per unit area in the study area (Table 1).

190 Table 1 Value coefficient of ecosystem services per unit area in the study area $\left(y u a n / \mathrm{hm}^{2}\right)$

\begin{tabular}{|c|c|c|c|c|c|c|c|}
\hline \multicolumn{2}{|c|}{ Ecosystem services type } & \multirow{2}{*}{$\begin{array}{l}\text { Cropland } \\
1298.15\end{array}$} & \multirow{2}{*}{$\begin{array}{l}\text { Forestland } \\
327.82\end{array}$} & \multirow{2}{*}{$\begin{array}{l}\text { Grassland } \\
393.38\end{array}$} & \multirow{2}{*}{$\begin{array}{l}\text { Water } \\
1049.01\end{array}$} & \multirow{2}{*}{$\begin{array}{l}\text { Bare land } \\
0.00\end{array}$} & \multirow{2}{*}{$\begin{array}{l}\text { Construction } \\
\text { land } \\
0.00\end{array}$} \\
\hline & Food production & & & & & & \\
\hline Provisioning & Raw material production & 406.49 & 760.53 & 590.07 & 301.59 & 0.00 & 0.00 \\
\hline serv1ces & Water supply & -944.11 & 393.38 & 327.82 & 10870.35 & 0.00 & 0.00 \\
\hline \multirow{4}{*}{$\begin{array}{l}\text { Regulation } \\
\text { services }\end{array}$} & Gas regulation & 1035.90 & 2504.51 & 2045.57 & 1009.67 & 26.23 & 0.00 \\
\hline & Climate regulation & 550.73 & 7487.29 & 5402.39 & 3002.79 & 0.00 & 0.00 \\
\hline & Purification environment & 157.35 & 2189.80 & 1783.31 & 7277.49 & 131.13 & 0.00 \\
\hline & Hydrological regulation & 1258.81 & 4904.11 & 3960.01 & 134063.22 & 39.34 & 0.00 \\
\hline \multirow{3}{*}{$\begin{array}{l}\text { Supporting } \\
\text { services }\end{array}$} & Soil conservation & 970.33 & 3042.12 & 2491.39 & 1219.47 & 26.23 & 0.00 \\
\hline & Maintain nutrient cycle & 183.58 & 236.03 & 196.69 & 91.79 & 0.00 & 0.00 \\
\hline & Biodiversity & 196.69 & 2779.87 & 2268.48 & 3343.71 & 26.23 & 0.00 \\
\hline $\begin{array}{l}\text { Cultural } \\
\text { services }\end{array}$ & Aesthetic landscape & 91.79 & 1219.47 & 996.56 & 2478.28 & 13.11 & 0.00 \\
\hline Total & & 5205.70 & 25844.93 & 20455.66 & 164707.37 & 262.25 & 0.00 \\
\hline
\end{tabular}

191 The ESV was calculated using the following equations:

$192 E S V_{k}=\sum_{f} A_{k} \times V C_{k f}$

$193 E S V_{f}=\sum_{k} A_{k} \times V C_{k f}$

$194 \mathrm{ESV}=\sum_{k} A_{k} \times V C_{k}$

195 where $\mathrm{ESV}_{k}, E S V_{f}$, and ESV refer to the ESVs of land use type $\mathrm{k}$, ecosystem service function

$196 \mathrm{f}$ and the entire value, respectively; $A_{k}$ is the area of land use type k; $V C_{k f}$ is the value coefficient

197 for land use type $\mathrm{k}$ with the ecosystem service function $\mathrm{j}$; and $V C_{k}$ represents the value coefficient

198 of land use type $\mathrm{k}$.

$199 \quad 2.4$ Ecological contribution rate of land use change

200 The contribution of the ecosystem service value of land use change refers to the change rate of the

201 regional ecosystem service value caused by the transformation of land use type $\mathrm{i}$ to land use type

202 j. The formula is as follows: 

where $E L_{i-j}$ is the contribution of land use change to the ecosystem service value; $V C_{j}$ and $V C_{i}$ represent the value coefficients of land use types $\mathrm{i}$ and $\mathrm{j}$, respectively; and $L U C_{i-j}$ is the area of land use type $i$ changed to land use type $\mathrm{j}$ during the study period. We calculated the sensitivity index by adjusting $50 \%$ of the value coefficient of various land use types.

\subsection{Sensitivity analysis}

Due to the uncertainty in the selection of the value coefficient, we conducted a sensitivity analysis to reflect the dependence of the ESV on the value coefficient over time. We calculate the sensitivity index by adjusting $50 \%$ of the value coefficient of various land use types up and down. The coefficients of sensitivity (CS) calculation process is as follows:

$\mathrm{CS}=\left|\frac{\left(E S V_{e}-E S V_{i}\right) / E S V_{i}}{\left(V C_{e k}-V C_{i k}\right) / V C_{i k}}\right|$

where CS is the coefficient of sensitivity; $E S V_{i}$ represents the initial ecosystem service values; $E S V_{e}$ represents the value of ecosystem services after adjustment; $V C_{i k}$ represents the initial value coefficient of land use type $\mathrm{i}$; and $V C_{e k}$ represents the value coefficient of land use type i after adjustment. If $\mathrm{CS}>1$, then $\mathrm{ESV}$ is elastic to the coefficient; that is, a $1 \% \mathrm{VC}$ change will lead to a more than $1 \% \mathrm{ESV}$ change. If $\mathrm{CS}<1$, then ESV is inelastic for the coefficient and the calculated results are reliable.

\subsection{Spatial auto-correlation analyses}

\subsubsection{Global spatial auto-correlation}

In this study, Moran's I, a global spatial autocorrelation model, was used to measure whether the spatial distribution of ecosystem service value was correlated. The calculation formula is as follows:

$\mathrm{I}=\frac{n}{\sum_{i=1}^{n} \sum_{j=1}^{n} W_{i j}} \times \frac{\sum_{i=1}^{n} \sum_{j=1}^{n} W_{i j}\left(x_{i}-\bar{x}\right)\left(x_{j}-\bar{x}\right)}{\sum_{i=1}^{n}\left(x_{i}-\bar{x}\right)^{2}}$

where $\mathrm{I}$ is the Moran index; $x_{i}$ and $x_{j}$ are the observations of space unit $\mathrm{i}$ and space unit $\mathrm{j}$, respectively; $\quad W_{i j}$ is the spatial weight matrix; $\bar{x}$ is the average of observations; and $\mathrm{n}$ is the sample size. The Moran's I index ranges from 1 to -1 . When Moran's I $>0$, it indicates a positive spatial correlation, and the larger the value is, the more obvious the spatial correlation; when Moran's $\mathrm{I}<0$, it indicates a negative spatial correlation, and the smaller the value is, the greater the spatial difference; when Moran's $\mathrm{I}=0$, the space presents randomness.

\subsubsection{Hot spot analysis}

To further study the local performance of ecosystem service changes in space, we used the GetisOrd $\mathrm{G}^{*}$ to analyse the local spatial autocorrelation. The specific formula is as follows:

$$
G i^{*}=\frac{\sum_{j=1}^{n} w_{i, j} x_{j}-\bar{X} \sum_{j=1}^{n} w_{i . j}}{s \sqrt{\frac{n \sum_{j=1}^{n} w_{i, j}^{2}-\left(\sum_{j=1}^{n} w_{i, j}\right)^{2}}{n-1}}}
$$

$\bar{X}=\frac{\sum_{j=1}^{n} x_{j}}{n}$

$\mathrm{S}=\sqrt{\frac{1}{n} \sum_{j=1}^{n} x_{j}^{2}-(\bar{X})^{2}}$

where $x_{j}$ is the attribute value of element $\mathrm{j} ; w_{i, j}$ is the spatial weight between elements $\mathrm{i}$ and $\mathrm{j} ; \mathrm{n}$ is the total number of elements; $\bar{X}$ is the mean value of elements; $\mathrm{S}$ is the standard deviation of the 

elements; and $\mathrm{Gi}^{*}$ is the Z-score. The higher the Z-score, the closer the clustering of high values (hot spots); the lower the Z-score, the closer the clustering of low values (cold spots).

\section{Results}

\subsection{Land use change during 2000-2015}

The temporal and spatial changes in land use are shown in Table 2 and Fig. 2. From 2000 to 2018, forestland was the most important land use type, accounting for more than $46 \%$, followed by cropland and grassland. The area of forestland increased from $46.12 \%$ in 2000 to $47.61 \%$ in 2018 . Cropland area decreased from $38.58 \%$ in 2000 to $37.24 \%$ in 2018 . Grassland was mainly distributed in the southwest region. From 2010 to 2018, its area decreased significantly from $12.88 \%$ to $10.35 \%$. The distribution of construction land was relatively concentrated, most of which was located in the urban area of Chongqing, and the area experienced an obvious change, with an increase of 1215.9 $\mathrm{km}^{2}$ from 2000 to 2018. Water was mainly distributed in the main stream of the Yangtze River and the reservoir area, and its area continued to expand. The proportion of water increased from $1.34 \%$ in 2000 to $1.9 \%$ in 2018 . Bare land covered less area and changed slightly.

From 2000 to 2018, the total land use transfer area in the TGRA was $22010.6 \mathrm{~km}^{2}$ (Table 3). Cropland, forestland and grassland were the main types of land transfer. The largest transferred area was cropland. The area transferred from other land types to cropland was $8458.71 \mathrm{~km}^{2}$, of which forestland contributed the most, accounting for $67.38 \%$. The area of cropland transferred to other land use types was $9227.47 \mathrm{~km}^{2}$, and the cropland area was reduced by $768.76 \mathrm{~km}^{2}$ in total. The area transferred from other land types to forestland was $8308.07 \mathrm{~km}^{2}$, and the area of forestland transferred to other land use types was $7453.24 \mathrm{~km}^{2}$, where the forestland increased by $854.83 \mathrm{~km}^{2}$. Grassland was mainly transformed into forestland and cropland, accounting for $45.53 \%$ and $51.98 \%$ of the change, respectively. A total of $3151.55 \mathrm{~km}^{2}$ of other land types was transferred into grassland, of which cropland contributed the most. In the transferred area of construction land, cropland contributed the most, with an area of $1091.56 \mathrm{~km}^{2}$, accounting for $79.39 \%$, followed by forestland and water, where the transferred areas were $182.92 \mathrm{~km}^{2}$ and $63.37 \mathrm{~km}^{2}$, respectively, accounting for $13.30 \%$ and $4.61 \%$. The water area of $373.02 \mathrm{~km}^{2}$ did not change. The area transferred from other land types to water was $713.76 \mathrm{~km}^{2}$. The area of water transferred to other land types was 399.33 $\mathrm{km}^{2}$, and the water area increased by $314.43 \mathrm{~km}^{2}$.

Table 2 Area of land use types in Three Gorges Reservoir area from 2000 to 2018

\begin{tabular}{|c|c|c|c|c|c|c|c|c|}
\hline \multirow{2}{*}{ Land use type } & \multicolumn{2}{|l|}{2000} & \multicolumn{2}{|l|}{2005} & \multicolumn{2}{|l|}{2010} & \multicolumn{2}{|l|}{2018} \\
\hline & $\operatorname{Area}\left(\mathrm{km}^{2}\right)$ & $\%$ & $\operatorname{Area}\left(\mathrm{km}^{2}\right)$ & $\%$ & Area $\left(\mathrm{km}^{2}\right)$ & $\%$ & Area $\left(\mathrm{km}^{2}\right)$ & $\%$ \\
\hline Cropland & 22171.98 & 38.58 & 21913.74 & 38.13 & 21584.95 & 37.56 & 21399.64 & 37.24 \\
\hline Forestland & 26507.15 & 46.12 & 26739.09 & 46.53 & 26779.74 & 46.60 & 27361.98 & 47.61 \\
\hline Grassland & 7560.83 & 13.16 & 7409 & 12.89 & 7404.21 & 12.88 & 5948 & 10.35 \\
\hline Water & 772.34 & 1.34 & 858.42 & 1.49 & 943.31 & 1.64 & 1090.37 & 1.90 \\
\hline Bare land & 9.56 & 0.02 & 7.17 & 0.01 & 7.17 & 0.01 & 3.5 & 0.01 \\
\hline Construction land & 449.54 & 0.78 & 543.99 & 0.95 & 752.02 & 1.31 & 1665.44 & 2.90 \\
\hline
\end{tabular}



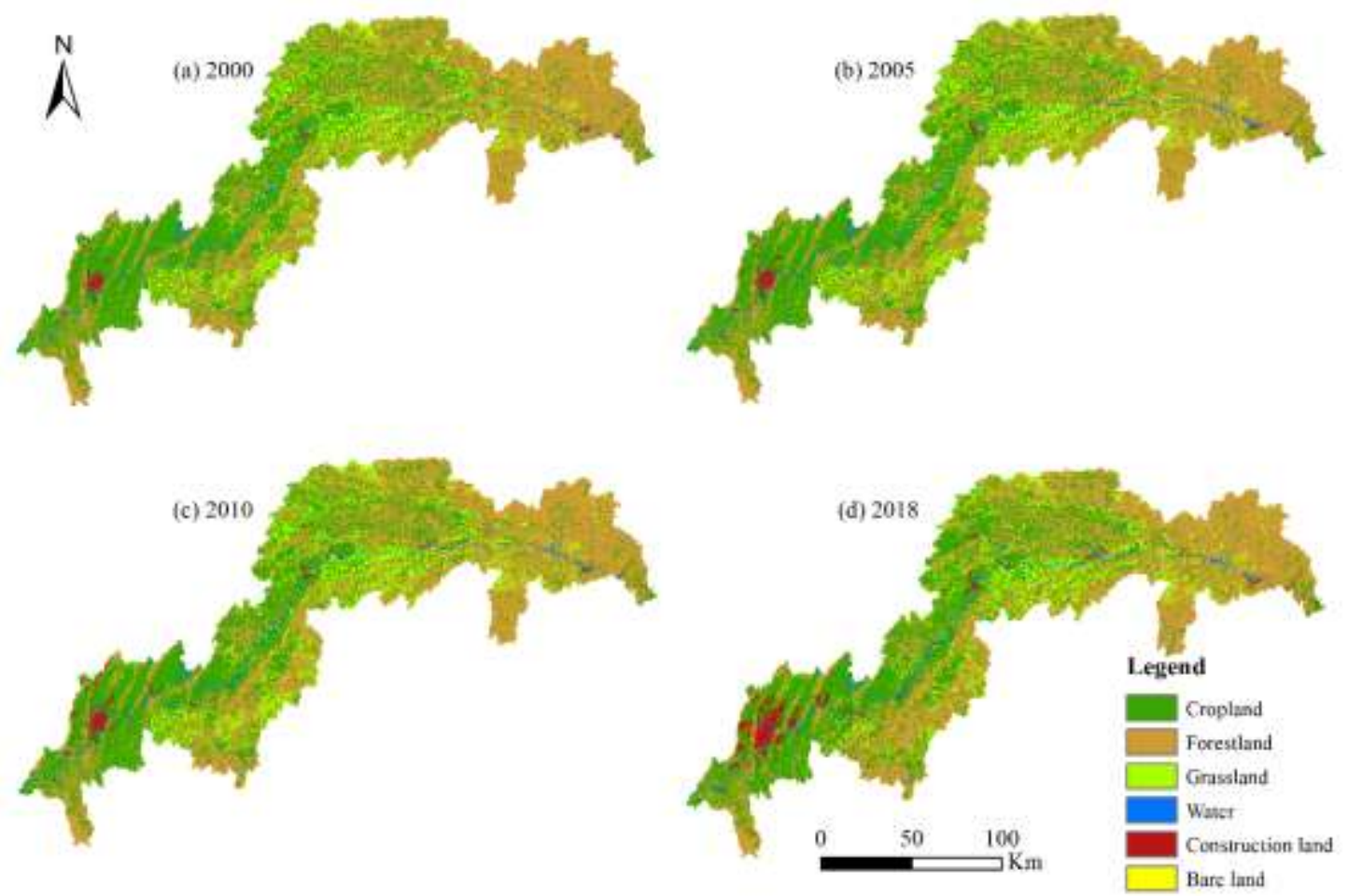

Fig. 2 Spatial distribution of land use/cover types in the Three Gorges Reservoir area

271 Table 3 Transition matrix of land use/cover change $\left(\mathrm{km}^{2}\right)$ in the Three Gorges Reservoir area from

$272 \quad 2000$ to 2018

\begin{tabular}{|c|c|c|c|c|c|c|c|}
\hline \multirow[b]{2}{*}{2000} & \multicolumn{7}{|c|}{2018} \\
\hline & Cropland & Forestland & Grassland & Water & $\begin{array}{c}\text { Construction } \\
\text { land }\end{array}$ & Bare land & $\begin{array}{c}\text { The area of } \\
\text { transferred } \\
\text { out }\end{array}$ \\
\hline Cropland & 12931.37 & 6010.17 & 1793.37 & 329.98 & 1091.56 & 2.39 & 9227.47 \\
\hline Forestland & 5699.32 & 19012.07 & 1315.14 & 254.66 & 182.92 & 1.2 & 7453.24 \\
\hline Grassland & 2474.85 & 2167.58 & 2789.28 & 82.49 & 35.87 & 0.00 & 4760.79 \\
\hline Water & 206.83 & 93.26 & 35.87 & 373.02 & 63.37 & 0.00 & 399.33 \\
\hline $\begin{array}{c}\text { Construction } \\
\text { land }\end{array}$ & 75.32 & 34.67 & 7.17 & 43.04 & 289.33 & 0.00 & 160.2 \\
\hline Bare land & 2.39 & 2.39 & 0 & 3.59 & 1.2 & 0.00 & 9.57 \\
\hline $\begin{array}{l}\text { The area of } \\
\text { transferred in }\end{array}$ & 8458.71 & 8308.07 & 3151.55 & 713.76 & 1374.92 & 3.59 & 22010.6 \\
\hline
\end{tabular}

\section{$273 \quad 3.2$ Change in ecosystem service value from $2000-2018$}

274 3.2.1 Temporal change of ecosystem service value

275 Based on the land use data, the ESVs were estimated (Table 4). From 2000 to 2018, the total value

276 of ecosystem services showed an upward trend, increasing from 78.5 billion yuan to 81.2 billion

277 yuan, with a total increase of 2.7 billion yuan. The ESV of forestland accounted for the largest

278 proportion at more than $62 \%$. Although the value of forestland ecosystem services increased, the

279 share declined first and then increased. The ESV of water increased the most, with an increase of

2803.8 billion yuan, which was because of its high value coefficient. The ESVs of cropland and 
grassland decreased by $3.48 \%$ and $21.33 \%$, respectively. The value of bare land decreased slightly, and the construction land remained unchanged.

283 Table 4 Ecosystem service value of different land use types (cropland, forestland, grassland, water, construction land, bare land) in the Three Gorges Reservoir area from 2000 to 2018 (104 yuan)

\begin{tabular}{|c|c|c|c|c|c|c|c|c|}
\hline \multirow[t]{2}{*}{ Land use types } & \multicolumn{2}{|l|}{2000} & \multicolumn{2}{|l|}{2005} & \multicolumn{2}{|l|}{2010} & \multicolumn{2}{|l|}{2018} \\
\hline & ESV & $\%$ & ESV & $\%$ & ESV & $\%$ & ESV & $\%$ \\
\hline Cropland & 837069.25 & 10.66 & 827319.79 & 10.39 & 814906.83 & 10.11 & 807910.73 & 9.95 \\
\hline Forestland & 4968394.41 & 63.29 & 5011868.31 & 62.93 & 5019487.59 & 62.28 & 5128620.33 & 63.15 \\
\hline Grassland & 1121658.05 & 14.29 & 1099133.89 & 13.80 & 1098423.28 & 13.63 & 882392.81 & 10.87 \\
\hline Water & 922569.62 & 11.75 & 1025393.23 & 12.88 & 1126795.38 & 13.98 & 1302460.36 & 16.04 \\
\hline Bare land & 18.18 & 0.01 & 13.64 & 0.0001 & 13.64 & 0.0001 & 6.83 & 0.0001 \\
\hline $\begin{array}{l}\text { Construction } \\
\text { land }\end{array}$ & 0.00 & 0.00 & 0.00 & 0.00 & 0.00 & 0.00 & 0.00 & 0.00 \\
\hline Total & 7849709.50 & 100 & 7963728.87 & 100 & 8059626.72 & 100 & 8121391.06 & 100 \\
\hline
\end{tabular}

285 As shown in Table 5, in terms of the ecosystem service functions, the ESV of regulation services

286 was the largest, accounting for $68 \%$, followed by supporting services and provisioning services,

287 while cultural services accounted for approximately 4\%, providing the lowest ESV. Supporting

288 services value and culture services value initially increased and then decreased, while provisioning

289 services value continuously increased. Among the ESVs of regulation services, hydrological

290 regulation contributed the most, reaching more than $40 \%$, followed by climate regulation and gas

291 regulation, which accounted for approximately $34 \%$ and 14\%, respectively. From 2000 to 2005, the

292 ESV of food production and maintenance of the nutrient cycle declined, while the value of other

293 ecosystem service functions increased. From 2005 to 2010, the ecosystem services that increased in

294 value were the water supply, climate regulation, purification environment, hydrological regulation,

295 biodiversity and aesthetic landscape. From 2010 to 2018, the value of ecosystem services of water

296 supply and hydrological regulation increased while the value of other ecosystem service functions

297 decreased.

298 Table 5 Ecosystem service value of different ecosystem service functions in the Three Gorges

299 Reservoir area from 2000 to $2018\left(10^{8}\right.$ yuan $)$

\begin{tabular}{|c|c|c|c|c|c|}
\hline \multirow{2}{*}{\multicolumn{2}{|c|}{ Ecosystem services functions }} & \multicolumn{4}{|l|}{ Value } \\
\hline & & 2000 & 2005 & 2010 & 2018 \\
\hline \multirow{3}{*}{$\begin{array}{l}\text { Provisioning } \\
\text { services }\end{array}$} & Food production & 29.92 & 29.75 & 29.52 & 29.18 \\
\hline & Raw material production & 24.56 & 24.57 & 24.51. & 24.18 \\
\hline & Water supply & 0.27 & 1.15 & 2.06 & 3.16 \\
\hline \multirow{4}{*}{$\begin{array}{l}\text { Regulation } \\
\text { services }\end{array}$} & Gas regulation & 76.59 & 76.65 & 76.53 & 75.40 \\
\hline & Climate regulation & 184.10 & 184.84 & 185.10 & 182.80 \\
\hline & Purification environment & 58.48 & 59.08 & 59.55 & 59.34 \\
\hline & Hydrological regulation & 211.32 & 219.85 & 227.93 & 239.95 \\
\hline \multirow{3}{*}{$\begin{array}{l}\text { Supporting } \\
\text { services }\end{array}$} & Soil conservation & 88.43 & 88.56 & 88.49 & 87.14 \\
\hline & Maintain nutrient cycle & 8.62 & 8.61 & 8.58 & 8.45 \\
\hline & Biodiversity & 70.91 & 71.30 & 71.54 & 70.65 \\
\hline Cultural services & Aesthetic landscape & 31.77 & 32.00 & 32.17 & 31.88 \\
\hline
\end{tabular}




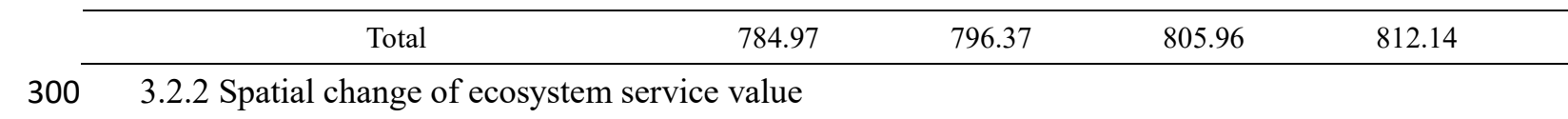

301 Fig. 3 shows the historical spatial distribution of ESV. The spatial distribution of ESV is affected by 302 the spatial pattern of land use in the study area. From 2000 to 2018, the distribution of extremely 303 high value areas of ESV was consistent with the spatial distribution of water, distributed in the main stream of the Yangtze River and the reservoir area. The extremely low areas of ESV were mainly distributed in the urban area of Chongqing, where the main type of land use was construction land. The low areas and high areas of ESV were scattered, and the spatial distribution of low value areas of ecosystem services was consistent with the distribution of cropland. From the perspective of the spatial evolution of ESV from 2000 to 2018, the extremely low areas and extremely high areas of ESV continued to expand due to the increase in construction land and water.
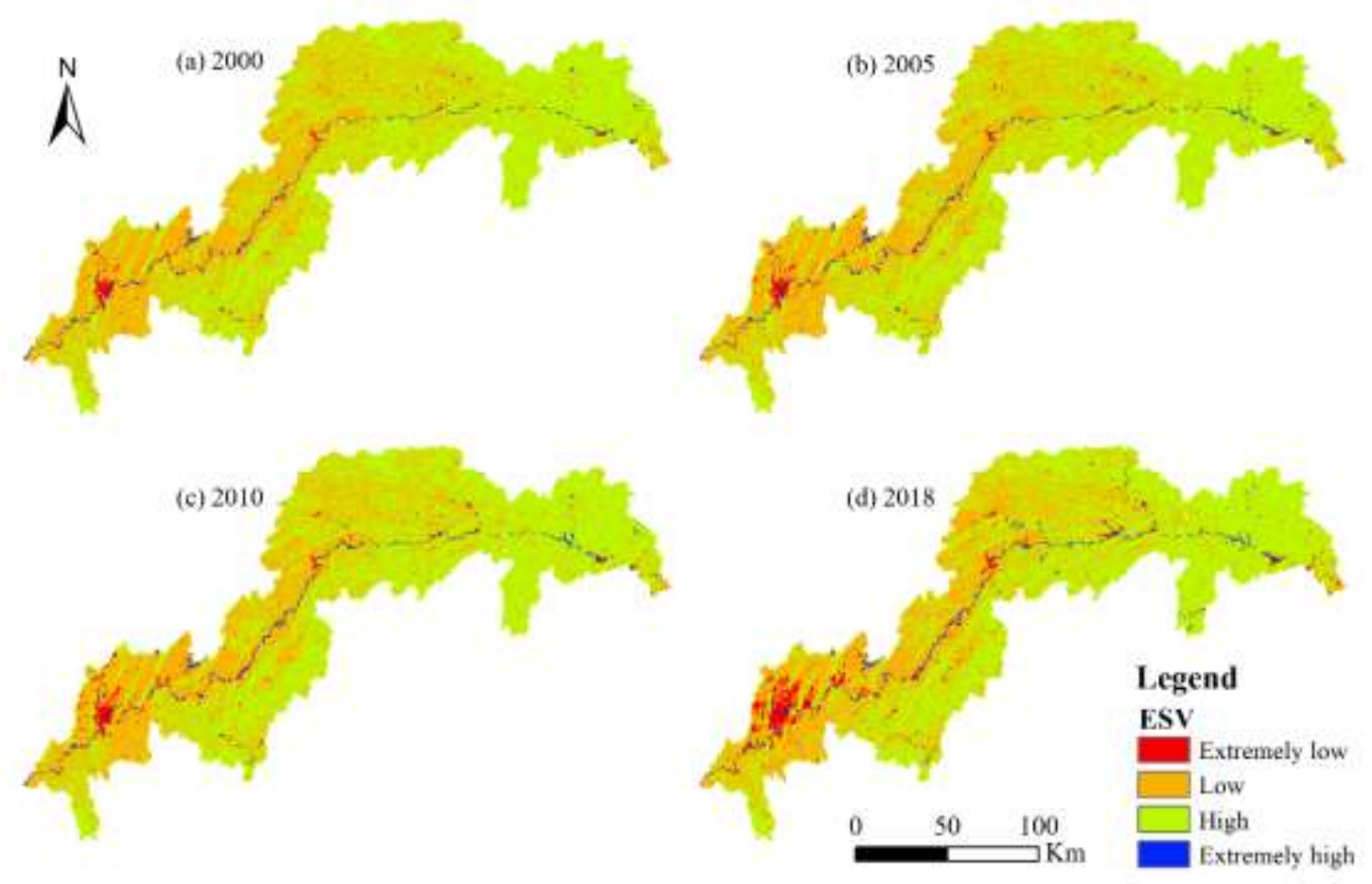

310

Fig. 3 Spatial distribution of ecosystem service value in the Three Gorges Reservoir area 3.2.3 Sensitivity analysis of ecosystem service value As shown in Fig. 4, the CS results in 2000, 2005, 2010, and 2018 were less than 1, indicating that the calculation result of CS was inelastic to the value coefficient. The estimation of ESV was in line with reality. Among the various land use types, the CS of forestland was the largest: 0.6228 0.6329. The smallest CS was bare land, which showed that the change in the value coefficient had the weakest impact on the ESV of bare land. 


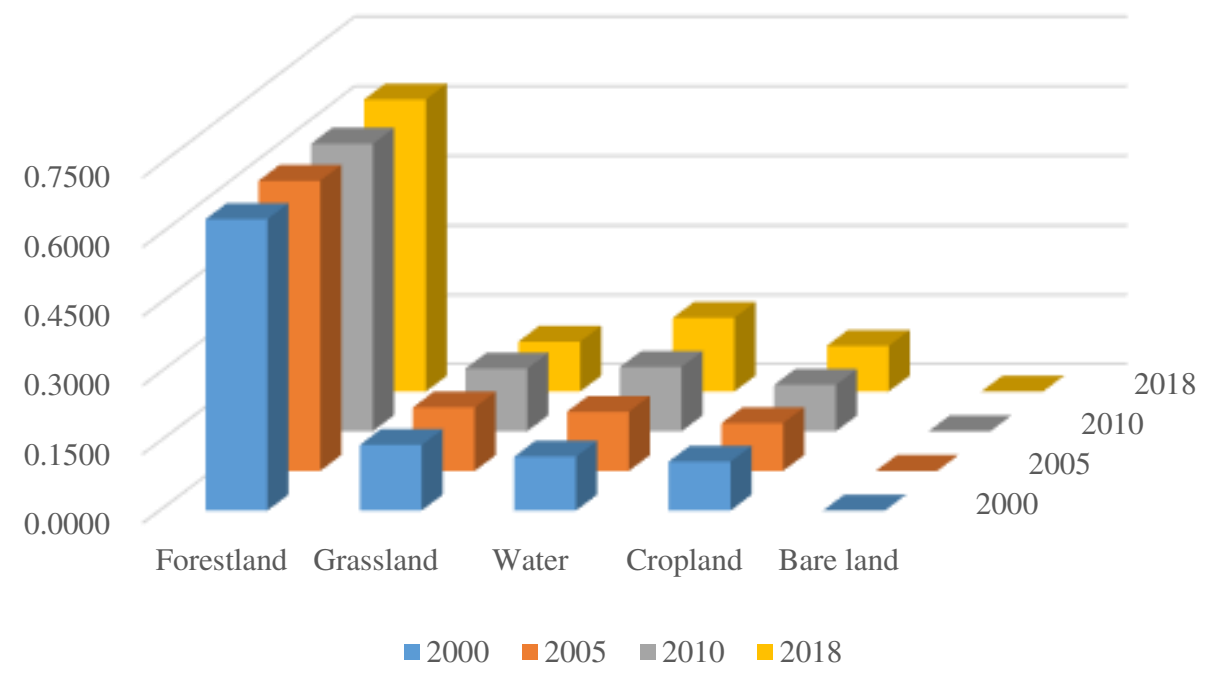

Fig. 4 Coefficient of sensitivity of ecosystem services value

\subsection{Impact of land use change on ecosystem service value}

The ecological environmental change caused by land use change in the TGRA showed a trend of both improvement and deterioration. According to the calculation of the contribution rate (Table 6), the land use changes improved the ESV in the TGRA during the study period. From 2000 to 2018, the conversion of cropland into forestland was the main factor in the improvement of ESV, with a contribution rate of $24.45 \%$. The continuous expansion of water had a positive influence on the ESV, with an increasing contribution rate from $60.92 \%$ for $2000-2005$ to $73.66 \%$ for $2005-2010$. The main types of land use transformation that led to the decrease in the value of ecosystem services included cropland reclamation and construction land occupation, and their contribution rates were $37.12 \%$ and $3.18 \%$, respectively. From 2000 to 2005, the conversion of grassland to cropland contributed $3.68 \%$ to the reduction in ESV. From 2005 to 2010, the occupation of cropland, forestland, water, and grassland by construction land contributed $11.33 \%$ to the reduction in ESV. From 2010 to 2018, the conversion of forestland, water and grassland into cropland was the main reason for the reduction in ESV, with contributions of $23.65 \%, 7.63 \%$ and $7.37 \%$, respectively. The overall change in the value of ecosystem services in the TGRA from 2000 to 2018 was not significant because the two trends of increase and decrease in ESVs occurred at the same time, and they offset each other in a certain area.

Table 6 Contribution of land use/cover change to ecosystem service value in Three Gorges Reservoir area from 2000 to 2018

\begin{tabular}{|c|c|c|c|c|c|c|c|c|}
\hline \multirow[b]{2}{*}{ pattern } & \multicolumn{2}{|c|}{$2000-2005$} & \multicolumn{2}{|c|}{$2005-2010$} & \multicolumn{2}{|c|}{ 2010-2018 } & \multicolumn{2}{|c|}{$2000-2018$} \\
\hline & $\begin{array}{l}\text { Land use } \\
\text { conversion } \\
\text { type }\end{array}$ & $\begin{array}{l}\text { Rate of } \\
\text { contribution } \\
1 \%\end{array}$ & $\begin{array}{l}\text { Land use } \\
\text { conversion } \\
\text { type }\end{array}$ & $\begin{array}{l}\text { Rate of } \\
\text { contribution } \\
1 \%\end{array}$ & $\begin{array}{l}\text { Land use } \\
\text { conversion } \\
\text { type }\end{array}$ & $\begin{array}{l}\text { Rate of } \\
\text { contribution } \\
1 \%\end{array}$ & $\begin{array}{l}\text { Land use } \\
\text { conversion } \\
\text { type }\end{array}$ & $\begin{array}{l}\text { Rate of } \\
\text { contribution } \\
1 \%\end{array}$ \\
\hline & $2-4$ & 35.96 & $1-4$ & 39.18 & $1-2$ & 23.81 & $1-2$ & 24.45 \\
\hline Ecosystem & $1-2$ & 19.43 & $2-4$ & 17.52 & $1-4$ & 9.38 & $1-4$ & 10.37 \\
\hline function & $1-4$ & 15.02 & $3-4$ & 11.49 & $2-4$ & 5.78 & $2-4$ & 6.97 \\
\hline improved & $3-4$ & 5.09 & $1-3$ & 5.57 & $1-3$ & 5.28 & $1-3$ & 5.39 \\
\hline & $5-4$ & 4.85 & $1-2$ & 5.48 & $3-2$ & 2.24 & $3-4$ & 2.35 \\
\hline
\end{tabular}




\begin{tabular}{|c|c|c|c|c|c|c|c|c|}
\hline & $3-2$ & 3.71 & $5-4$ & 5.47 & $3-4$ & 2.07 & $3-2$ & 2.30 \\
\hline & $1-3$ & 2.69 & $3-2$ & 2.00 & $5-4$ & 1.61 & $5-4$ & 1.40 \\
\hline & Other & 1.93 & & & Other & 0.63 & Other & 0.41 \\
\hline & Total & 88.69 & Total & 86.72 & Total & 50.80 & Total & 53.64 \\
\hline \multirow{9}{*}{$\begin{array}{l}\text { Ecosystem } \\
\text { function } \\
\text { deteriorates }\end{array}$} & $3-1$ & 3.68 & $1-5$ & 5.25 & $2-1$ & 23.65 & $2-1$ & 23.18 \\
\hline & $2-1$ & 2.43 & $2-5$ & 2.40 & $4-1$ & 7.63 & $3-1$ & 7.44 \\
\hline & $1-5$ & 2.18 & $4-5$ & 2.19 & $3-1$ & 7.37 & $4-1$ & 6.50 \\
\hline & $2-5$ & 1.06 & $3-5$ & 1.49 & $4-2$ & 3.45 & $4-2$ & 2.55 \\
\hline & $4-5$ & 0.97 & $2-3$ & 0.82 & $4-5$ & 2.21 & $4-5$ & 2.06 \\
\hline & $3-5$ & 0.60 & $2-1$ & 0.82 & $2-3$ & 1.46 & $2-3$ & 1.40 \\
\hline & $2-3$ & 0.38 & $3-1$ & 0.30 & $4-3$ & 1.45 & $1-5$ & 1.12 \\
\hline & & & & & Other & 1.99 & Other & 2.10 \\
\hline & Total & 11.31 & Total & 13.28 & Total & 49.2 & Total & 46.36 \\
\hline
\end{tabular}

339 1 6 respectively represent 6 types of land use (1: Cropland; 2: Forestland; 3: Grassland; 4: Water; 5: Construction

340 land; 6: Bare land). 1-2 represents the conversion of cropland to forestland, other codes and so on

\section{$341 \quad 3.4$ Spatial auto-correlation analysis}

342 3.4.1 Global spatial autocorrelation of ecosystem service value

343 As shown in Table 7, the global Moran's I of the ESV in 2000, 2005, 2010, and 2018 was 0.5294,

$3440.5365,0.5396$, and 0.5135 , respectively. The results indicate that the spatial distribution of the ESV

345 in the study area had a strong positive correlation and significant clustering. Moran's I of the ESV

346 first increased and then decreased in the four periods, which shows that the cluster phenomenon of

347 the spatial distribution of the ESV in the study area first strengthened and then weakened. Analysing

348 the spatial autocorrelation of the dynamic changes in ESV, the results show that the global Moran's

349 I decreased, which also had obvious spatial aggregation.

350 Table 7 Moran's I of the ecosystem service value in Three Gorges Reservoir region

\begin{tabular}{cccc}
\hline Year & Moran's I & $\mathrm{P}$ & $\mathrm{Z}$ \\
\hline 2000 & 0.5294 & $<0.001$ & 179.63 \\
2005 & 0.5365 & $<0.001$ & 182.05 \\
2010 & 0.5396 & $<0.001$ & 183.08 \\
2018 & 0.5135 & $<0.001$ & 174.24 \\
$2000-2005$ & 0.4706 & $<0.001$ & 160.03 \\
$2005-2010$ & 0.4684 & $<0.001$ & 159.29 \\
$2010-2018$ & 0.2940 & $<0.001$ & 99.71 \\
$2000-2018$ & 0.3165 & $<0.001$ & 107.33 \\
\hline
\end{tabular}

351

352

353

354

355

356

357

3.4.2 Hot spot analysis of ecosystem service value

The statistically significant hot spots and cold spots are shown in Fig. 5. From 2000 to 2018, the hot spots of ESV change were mainly distributed in the main stream of the Yangtze River and the reservoir area. This is mainly due to the water impoundment of the Three Gorges Project and ecological policies, which resulted in the conversion of land use types from cropland and forestland to water and cropland to forestland, thus leading to the increase in ESV. The cold spots of ESV change had a small proportion of area and were mainly distributed around water areas (Table 8). 
This is because the local residents live by the water, resulting in the increase of construction land around the water, which reduced the value of ecosystem services. From 2000 to 2005, the hot spots of ESV change were mainly distributed in Zigui, Badong, Shizhu and Kaizhou because the conversion of forestland to water or cropland to forestland led to an increase in the value of local ecosystem services. The cold spots of ESV change were scattered. From 2005 to 2010, the hot spot and cold spot areas were reduced at the same time. The hot spots were distributed in the Chongqing section of the TGRA. The increasing water storage height of the Three Gorges Project led to the expansion of the local water area, which increased the ESV. Compared with 2005 to 2010, the area of cold and hot spots expanded from 2010 to 2018. From the spatial perspective of cold and hot spots, the cold spots and hot spots were more concentrated and obvious. In each time period, the area of the hot spots was significantly larger than that of the cold spots, which also verified that the ESV of the TGRA was characterized by rising changes during the study period.
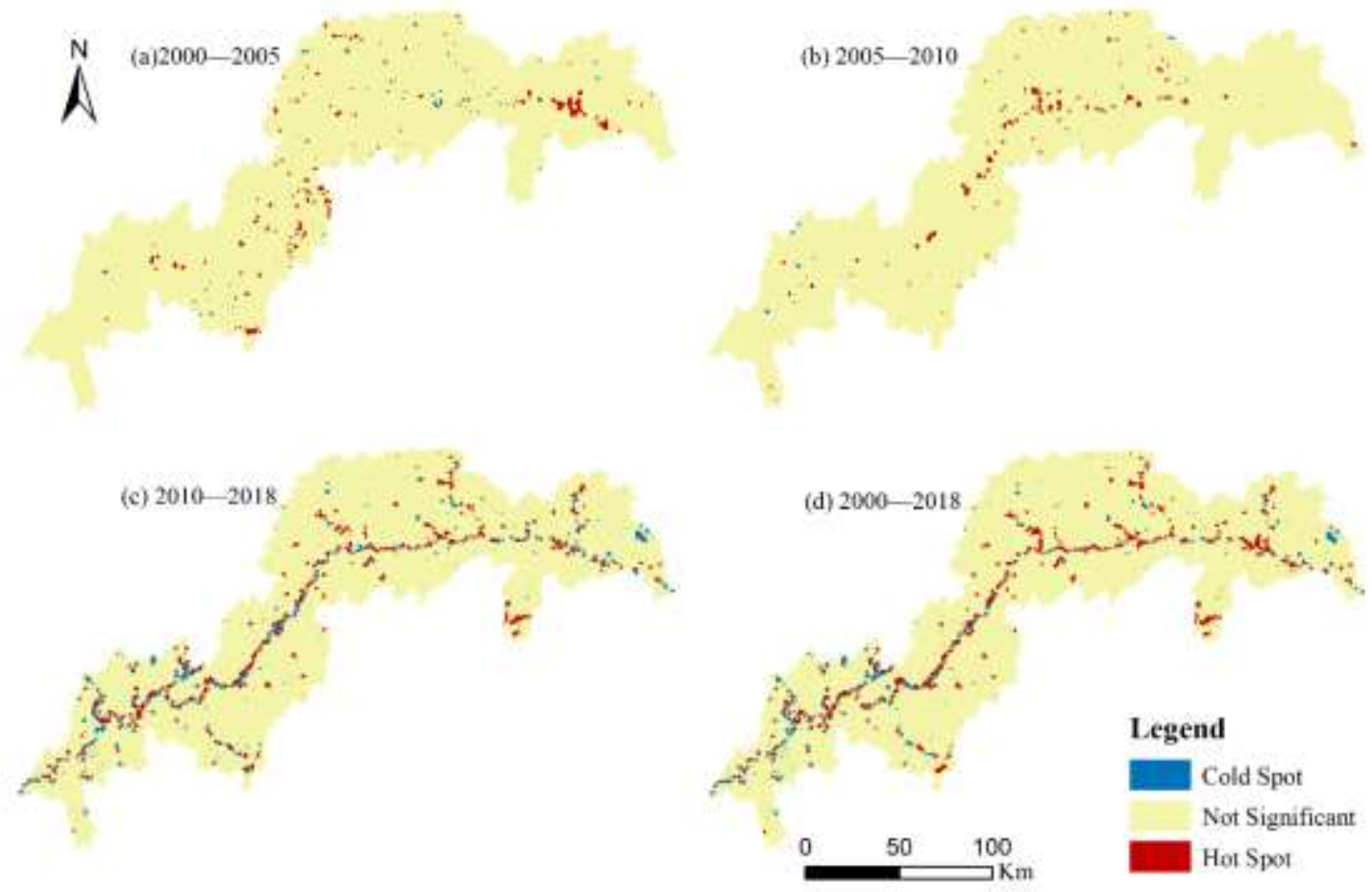

Fig. 5 Spatial distribution of cold spots and hot spots of ecosystem service value changes in the Three Gorges Reservoir area from 2000 to 2018

Table 8 Area proportion of cold spots and hot spots of ecosystem service value changes in Three Gorges Reservoir area from 2000 to 2018

\begin{tabular}{lllll}
\hline Phases & $2000-2005$ & $2005-2010$ & $2010-2018$ & $2000-2018$ \\
\hline Cold spot & 0.36 & 0.19 & 3.33 & 2.82 \\
Hot spot & 1.79 & 1.27 & 4.21 & 4.78 \\
Not significant & 97.85 & 98.54 & 92.46 & 92.4 \\
\hline
\end{tabular}

\section{Discussion}

\subsection{Characteristics of land use change in the TGRA for different periods}

The main construction projects in each stage of the Three Gorges Project were different, so the relevant land use change characteristics and their driving factors were likely to be different (Fig. 6). Therefore, in this study, we not only analysed the characteristics of LUC and its transfer during the 
entire study period (2000-2018) but also for each five-year construction period of the Three Gorges Project, which was missing in most previous studies (Jiang et al. 2008). According to the specific results of the period, we obtained the specific characteristics of land use changes during the three construction periods, which strengthened the practical application of decision makers.

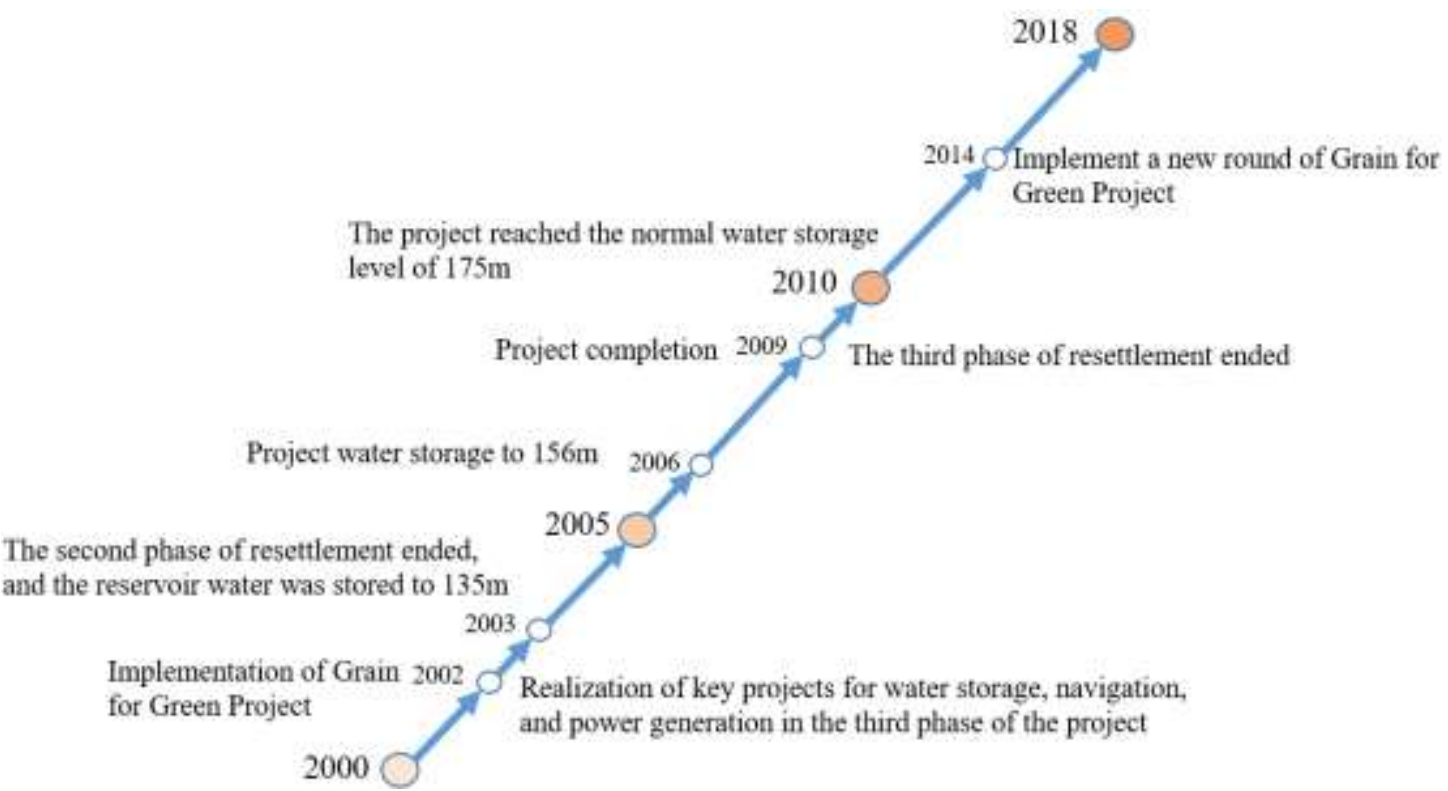

Fig. 6 Main driving factors of land use changes in the Three Gorges Reservoir area from 2000 to 2018

From 2000 to 2005, the closure of the Yangtze River led to the expansion of water. Forestland, cropland, grassland and construction land were transferred into water, and the reservoir area was filled with water up to 135 metres. The increase in water area was also the main feature of LUC in the TGRA from 2005 to 2010, which was due to the continuous storage of water in the reservoir. In October 2010, the Three Gorges Project successfully achieved the experimental water storage target of 175 metres. The Three Gorges Reservoir inundated a land area of $632 \mathrm{~km}^{2}$, including two medium-sized cities, Wanzhou and Fuling, and more than 10 small cities. At the same time, the main works of the Three Gorges Project and the resettlement of a million people were also announced to be completed. The water storage of the Three Gorges Project led to inundation at low altitudes, and local residents needed to rebuild their homes in higher altitude areas. Eighty percent of the resettlers resettled the reservoir area, resulting in excessive cultivation of cropland. At the same time, all the submerged professional facilities needed to be rebuilt, such as roads and bridges. The adjustment of regional centre orientation and transportation hubs had a great impact on the layout of construction land, cropland, forestland and grassland in the TGRA. From 2010 to 2018, the policy of the Grain for Green Project showed significant effects, with part of the cropland turning into forestland. Zigui County is the head of the dam of the Three Gorges Project and is the national technology demonstration site for the Grain for Green Project. At the end of 2012, the forest area and forest coverage reached $17.9 \mathrm{hm}^{2}$ and $78.98 \%$, respectively, increasing by $15 \%$ and $11.2 \%$ compared with before the implementation of the Grain for Green Project. Through ecological construction, the forest area and stock volume in the TGRA have increased substantially, and the forest coverage rate in the reservoir area has reached $58.49 \%$, which was $18 \%$ higher than the average level in the Yangtze River Basin. In addition, with the development of the social economy, the average urbanization rate in the reservoir continued to rise, from $42.19 \%$ in 2010 to $59.56 \%$ in 2018 , and the 
area of construction land continued to expand.

\subsection{Impact of land use change on ESV}

The impact of LUC on the value of ecosystem services is very complex, and the changes in land use will lead to changes in ecosystem service structure and function. During the study period, the value of ecosystem services increased due to the implementation of the policy of the Grain for Green Project (Wang et al. 2019b) and the impoundment of the Three Gorges Project, which led to significant changes in land use structure, especially in grassland and water. On the other hand, the expansion of construction land caused by urbanization and resettlement had a certain negative impact on ecosystem services (Chu et al. 2018). Similar to this finding, from 2000 to 2015, the decrease in cropland and the increase in construction land led to a decrease in ecosystem services in Jiangsu Province (Wu et al. 2020). Similarly, the total amount of ecosystem services in Poyang Lake declined due to the decrease in cropland and the sharp increase in construction land (Yuan et al. 2021). The study found that a $1 \mathrm{~km}^{2}$ area of cropland transforming to construction land corresponds to an ESV decrease of $2.1 \times 10^{6}$ yuan. The direction of the total change in ESV from 2000 to 2018 revealed by this study is consistent with Wang et al. (2020) research results, but there are certain differences in the results of the value. The reason is the use of different research methods. Wang et al. (2020) used the alternative cost method, shadow engineering method, carbon tax method, market value method and water balance method to quantify the value of ecosystem services in the TGRA from 2000 to 2015.

From the perspective of contribution rate, during the study period, the conversion of cropland to forestland contributed the most to the increase in ecosystem services. It is mainly the implementation of the policy of Grain for Green Project, Natural Forest Protection Program and Yangtze River Basin Shelter Forest Project. It is worth mentioning that although the area of water did not increase much, it has a great impact on the ecosystem of the reservoir area, which is similar to the conclusion of Zhang et al. (2015). They believed that water bodies played major roles in ecosystem services in the Chaohu Lake Basin, which is mainly because the equivalent factor coefficient of water is higher than that of other land use types. Compared with other land use types, water has stronger ecological functions (Acuna-Alonso et al. 2021; Aznar-Sánchez et al. 2019), such as water supply and hydrological regulation. In addition, the increase in water area mainly occurred in the main stream of the Yangtze River and surrounding the reservoir area, so the ESV in the area was high. The conversion of forestland to cropland had the largest contribution rate to the reduction in ESV in the study area. The conversion of forestland to cropland led to the loss of regional ecosystem services. At the same time, the expansion of construction land has adversely affected the value of ecosystem services. In general, the Three Gorges Project water storage and Grain for Green Project have played an important positive role in the value of ecosystem services in the TGRA, and urbanization and resettlement had a certain negative impact on ESVs. Land use changes may significantly affect ecosystems, but they do not necessarily lead to ecosystem degradation (Yi et al. 2016).

\subsection{Policy implications}

During the study period, the land use changes in the TGRA were active, with a large increase in construction land and decrease in cropland. Future land planning should strengthen the protection of ecological land such as water, forestland and cropland and focus on optimizing and controlling the spatial pattern of land use. It is significant to find the conjunct point between economic 
development and the protection of ecological land, which is the fundamental method of determining the sustainable development of the TGRA.

The TGRA is an important ecological barrier area. The construction of the Three Gorges Project has caused a series of impacts on the ecological environment of the region. However, the value of ecosystem services showed a steadily increasing trend during the study period, indicating that the ecological policies of the Grain for Green Project have made effective progress in recent years. In the future, ecological construction should still be given priority, and the core task is to intensify efforts to close mountains and cultivate forests and promote ecological environmental protection policies. Moreover, because of the regional development status and local conditions, the development of green and pollution-free industries should be given priority to ensure the simultaneous development of resources and ecological restoration. While developing the economy, damage to the environment should be minimized to achieve stability and improvement of the regional environment.

The main urban area of Chongqing in the TGRA was the place with the lowest value of ecosystem services. Through the spatial distribution of the ESV, it is possible to identify ecological control areas, formulate reasonable territorial spatial planning, strengthen the control of the ecological protection redline (Yang et al. 2020), and restore the ecosystem. In addition, understanding the ESV of the TGRA can help establish an ecological compensation mechanism and explore ways to realize the value of diversified ecological products (Fan \&Chen 2019).

\subsection{Limitations}

This study used the benefit transfer method to estimate the value of ecosystem services. This method is widely used because of the low cost of collecting primary data and the ability to quickly assess the value. However, it has been criticized due to its uncertainty and reliability. The classification and accuracy of land use data and the method of modifying the equivalent table can affect the evaluation results of ESV. Although our assessment results may not be the most accurate, they can reflect the changing trend of ESV in the TGRA and serve as a reference for further research. In addition, there is a lack of quantitative analysis on the complex driving forces of ESV change, which should be further explored in the future.

\section{Conclusions}

This study estimated the spatiotemporal changes in ESVs in the TGRA from 2000 to 2018 and analysed the impact of land use on the ESVs. The main research conclusions are as follows:

(1) Forestland and cropland were the most important land use types from 2000 to 2018, and they accounted for $80 \%$ of the TGRA. At the same time, the land use in the study area has also undergone tremendous changes, among which grassland and construction land were the largest land use types with area reduction and increase.

(2) From 2000 to 2018, due to the expansion of water and the increase in forestland and construction land, the ESV of the study area increased by 2.7 billion yuan, with a growth rate of $3.46 \%$. From the perspective of contribution rate, the conversion of cropland to forestland had the largest contribution rate to the increase in ESV, and the conversion of forestland to cropland had the largest contribution rate to the reduction in ESV.

(3) The ESV in the study area had prominent spatiotemporal changes, significant spatial correlation and high spatial clustering. From 2000 to 2018, the hot spots of ESV change were mainly distributed in the main stream of the Yangtze River and the reservoir area, and the cold and hot 
spots had a small proportion of the area.

(4) The main reasons for the changes in ESV in the study area were the water impoundment of the Three Gorges Project, the Three Gorges Project resettlement, urbanization development and ecological policies, such as the Grain for Green Program.

\section{References}

Acuna-Alonso C, Fernandes ACP, Alvarez X, Valero E, Pacheco FAL, Varandas S, Terencio DPS, Fernandes LFS (2021) Water security and watershed management assessed through the modelling of hydrology and ecological integrity: A study in the Galicia-Costa (NW Spain). Sci Total Environ 759:143905. https://doi.org/10.1016/j.scitotenv.2020.143905

Aznar-Sánchez JA, Velasco-Muñoz JF, Belmonte-Ureña LJ, Manzano-Agugliaro F (2019) The worldwide research trends on water ecosystem services. Ecol Indic 99:310-323. https://doi.org/10.1016/j.ecolind.2018.12.045

Cao T, Yi Y, Liu H, Xu Q, Yang Z (2021) The relationship between ecosystem service supply and demand in plain areas undergoing urbanization: A case study of China's Baiyangdian Basin. J Environ Manage 289:112492. https://doi.org/10.1016/j.jenvman.2021.112492

Chu L, Sun T, Wang T, Li Z, Cai C (2018) Evolution and Prediction of Landscape Pattern and Habitat Quality Based on CA-Markov and InVEST Model in Hubei Section of Three Gorges Reservoir Area (TGRA). Sustainability 10:3854-3882. https://doi.org/10.3390/su10113854

Costanza R, d'Arge R, Groot Rd, Farber S, Grasso M, Hannon B, Limburg K, Naeem S, O'Neill RV, Paruelo J, Raskin RG, Sutton P, Belt Mvd (1997) The value of the world's ecosystem services and natural capital. Nature 387:253-260.

Daily (1997) Nature's Services: Societal Dependence on Natural Ecosystems. Island Press, Washington

Fan M, Chen L (2019) Spatial characteristics of land uses and ecological compensations based on payment for ecosystem services model from 2000 to 2015 in Sichuan Province, China. Ecological Informatics 50:162-183. https://doi.org/10.1016/j.ecoinf.2019.01.001

Feng L, Xu JY (2015) Farmers' Willingness to Participate in the Next-Stage Grain-for-Green Project in the Three Gorges Reservoir Area, China. Environ Manag. https://doi.org/10.1007/s00267-0150505-1

Fu BJ, Zhang LW (2014) Land-use change and ecosystem services: concepts, methods and progress. Progress in Geography 33(4):441-446. https://doi.org/10.11820/dlkxjz.2014.04.001

Gashaw T, Tulu T, Argaw M, Worqlul AW, Tolessa T, Kindu M (2018) Estimating the impacts of land use/land cover changes on Ecosystem Service Values: The case of the Andassa watershed in the Upper Blue Nile basin of Ethiopia. Ecosyst Serv 31:219-228. https://doi.org/10.1016/j.ecoser.2018.05.001

Guo HL, Zhou Q (2016) Effect of land use change onecosystem service value pre and post the water storage in the Three Gorges Reservoir Area. Res Soil Water Conserv 23(5):222-228. https://doi.org/10.13869/j.cnki.rswc.20160617.005

Hasan SS, Zhen L, Miah MG, Ahamed T, Samie A (2020) Impact of land use change on ecosystem services: A review. Environmental Development 34:100527. https://doi.org/10.1016/j.envdev.2020.100527

Holbach A, Floehr T, Kranzioch I, Wolf A (2013) Dilution of pollution? Processes affecting the water quality in the river-style Three Gorges Reservoir. Environ Sci Pollut Res 20:7140-7141. https://doi.org/10.1007/s11356-012-1252-y 
Huang CB, Huang X, Peng CH, Zhou ZX, Teng MJ, Wang PC (2019) Land use/cover change in the Three Gorges Reservoir area, China: Reconciling the land use conflicts between development and protection. Catena 175:388-399. https://doi.org/10.1016/j.catena.2019.01.002

Huang CB, Zhou ZX, Teng MJ, Wu CG, Wang PC (2020) Effects of climate, land use and land cover changes on soil loss in the Three Gorges Reservoir area, China. Geography and Sustainability 1:200-208. https://doi.org/10.1016/j.geosus.2020.08.001

Jiang YH, Jiang H, Zeng B, He BH (2008) Effects of land use change on the ecosystem services value of Three Gorges Reservoir Area (the part of Chongqing). Res Soil Water Conserv 15:234-237

Li F, Zhang SW, Yang JC, Chang LP, Yang HJ, Bu K (2018) Effects of land use change on ecosystem services value in West Jilin since the reform and opening of China. Ecosyst Serv 31:12-20. https://doi.org/10.1016/j.ecoser.2018.03.009

Li N, Wang JY, Wang HY, Fu BL, Chen JJ, He W (2021) Impacts of land use change on ecosystem service value in Lijiang River Basin, China. Environ Sci Pollut Res 1-16. https://doi.org/10.1007/s11356-020-12190-0

Li SC, Bing ZL, Jin G (2019a) Spatially Explicit Mapping of Soil Conservation Service in Monetary Units Due to Land Use/Cover Change for the Three Gorges Reservoir Area, China. Remote Sensing 11:468-489. https://doi.org/10.3390/rs11040468

Li Z, Ma JR, Guo JS, Paerl HW, Brookes JD, Xiao Y, Fang F, Ouyang WJ, Lu LH (2019b) Water quality trends in the Three Gorges Reservoir region before and after impoundment (1992-2016). Ecohydrology \& Hydrobiology 19:317-327. https://doi.org/10.1016/j.ecohyd.2018.08.005

Liang J, Li S, Li XD, Li X, Liu Q, Meng QF, Lin AQ, Li JJ (2021) Trade-off analyses and optimization of water-related ecosystem services (WRESs) based on land use change in a typical agricultural watershed, southern China. J Clean Prod 279:123851. https://doi.org/10.1016/j.jclepro.2020.123851

Liu LM, Wu JG (2021) Ecosystem services-human wellbeing relationships vary with spatial scales and indicators: The case of China. Resources, Conservation and Recycling 172:105662. https://doi.org/10.1016/j.resconrec.2021.105662

Liu YB, Hou XY, Li XW, Song BY, Wang C (2020) Assessing and predicting changes in ecosystem service values based on land use/cover change in the Bohai Rim coastal zone. Ecol Indic 111:106004. https://doi.org/10.1016/i.ecolind.2019.106004

Millennium Ecosystem Assessment (2005) Ecosystems and Human Well-Being: Synthesis. Island Press, Washington DC

Schirpke U, Tscholl S, Tasser E (2020) Spatio-temporal changes in ecosystem service values: Effects of land-use changes from past to future (1860-2100). J Environ Manage 272:111068. https://doi.org/10.1016/j.jenvman.2020.111068

Shao JA, Zhang SC, Wei CF (2013) Remote sensing analysis of land use change in the Three Gorges Reservoir area, based on the construction phase of large-scale water conservancy project. Geographical Research 32(12):2189-2203. https://doi.org/10.11821/dlyj201312002

Tan Z, Guan QY, Lin JK, Yang LQ, Luo HP, Ma YR, Tian J, Wang QZ, Wang N (2020) The response and simulation of ecosystem services value to land use/land cover in an oasis, Northwest China. Ecol Indic 118:106711. https://doi.org/10.1016/j.ecolind.2020.106711

Wang CD, Li X, Yu HJ, Wang YT (2019a) Tracing the spatial variation and value change of ecosystem services in Yellow River Delta, China. Ecol Indic 96:270-277. https://doi.org/10.1016/j.ecolind.2018.09.015 
Wang DJ, Wei HY, He M, Gu Q, Ma MG, Li J (2020) Temporal and spatial patterns of ecosystem services value in the Three Gorges Reservoir Area based on land use. Resources and Environment in the Yangtze Basin 29:90-100. https://doi.org/10.11870/cjlyzyyhj202001009

Wang J, Dun YL (2015) A review on the effects of land use change on ecosystem services. Resources and Environment in the Yangtze Basin 24:798-808. https://doi.org/10.11870/cjlyzyyhj201505012

Wang YC, Zhao J, Fu JW, Wei W (2019b) Effects of the Grain for Green Program on the water ecosystem services in an arid area of China-Using the Shiyang River Basin as an example. Ecol Indic 104:659-668. https://doi.org/10.1016/j.ecolind.2019.05.045

Wu CY, Chen BW, Huang XJ, Dennis Wei YH (2020) Effect of land-use change and optimization on the ecosystem service values of Jiangsu province, China. Ecol Indic 117:106507. https://doi.org/10.1016/j.ecolind.2020.106507

Wu JG, Huang JH, Han XG, Xie ZQ, Gao XM (2003) Three-Gorges Dam -- Experiment in Habitat Fragmentation? Science 300:1239-1240. http://www.jstor.org/stable/3834070

Wu XT, Wang S, Fu BJ, Liu Y, Zhu Y (2018) Land use optimization based on ecosystem service assessment: A case study in the Yanhe watershed. Land Use Policy 72:303-312. https://doi.org/10.1016/j.landusepol.2018.01.003

Xiang R, Wang LJ, Li H, Tian ZB, Zheng BH (2021) Temporal and spatial variation in water quality in the Three Gorges Reservoir from 1998 to 2018. Sci Total Environ 768:144866. https://doi.org/10.1016/j.scitotenv.2020.144866

Xiao Y, Xiao Q, Xiong QL, Yang ZP (2020) Effects of Ecological Restoration Measures on Soil Erosion Risk in the Three Gorges Reservoir Area Since the 1980s. Geohealth 4:1-13. https://doi.org/10.1029/2020GH000274

Xie GD, Zhen L, Lu CX, Xiao Y, Chen C (2008) Expert knowledge based valuation method of ecosystem services in China. J Nat Resour 23:911-919

Xie GD, Zhang CX, Zhang LM, Chen WH, Li SM (2015) Improvement of the evaluation method for ecosystem service value based on per unit area. J Nat Resour 30:1243-1254. https://doi.org/10.11849/zrzyxb.2015.08.001

Yan EP, Lin H, Wang GX, Xia CZ (2014) Analysis of evolution and driving force of ecosystem service values in the Three Gorges Reservoir region during 1990-2011. Acta ecologica sinica 34:59625973. https://doi.org/10.5846/stxb201312263032

Yang YJ, Song G, Lu S (2020) Study on the ecological protection redline (EPR) demarcation process and the ecosystem service value (ESV) of the EPR zone: A case study on the city of Qiqihaer in China. Ecol Indic 109:105754. https://doi.org/10.1016/j.ecolind.2019.105754

Yi L, Zhang ZX, Zhao XL, Liu B, Wang X, Wen QK, Zuo LJ, Liu F, Xu JY, Hu SG (2016) Have Changes to Unused Land in China Improved or Exacerbated Its Environmental Quality in the Past Three Decades? Sustainability 8:184-199. https://doi.org/10.3390/su8020184

Yu L, Lyu YC, Chen C, Choguill CL (2020) Environmental deterioration in rapid urbanisation: evidence from assessment of ecosystem service value in Wujiang, Suzhou. Environment, Development and Sustainability 23:331-349. https://doi.org/10.1007/s10668-019-00582-3

Yuan XZ, Zhang YW, Liu H, Xiong S, Li B, Deng W (2013) The littoral zone in the Three Gorges Reservoir, China: challenges and opportunities. Environ Sci Pollut Res 20:7092-7102. https://doi.org/10.1007/s11356-012-1404-0

Yuan Z, Xu JJ, Wang YQ, Yan B (2021) Analyzing the influence of land use/land cover change on 
landscape pattern and ecosystem services in the Poyang Lake Region, China. Environ Sci Pollut Res 28:27193-27206. https://doi.org/10.1007/s11356-020-12320-8

Zhang J, Qu M, Wang C, Zhao J, Cao Y (2020a) Quantifying landscape pattern and ecosystem service value changes: A case study at the county level in the Chinese Loess Plateau. Global Ecology and Conservation 23:e01110. https://doi.org/10.1016/j.gecco.2020.e01110

Zhang Q, Chen CL, Wang JZ, Yang DY, Zhang Y, Wang ZF, Gao M (2020b) The spatial granularity effect, changing landscape patterns, and suitable landscape metrics in the Three Gorges Reservoir Area, 1995-2015. Ecol Indic 114:106259. https://doi.org/10.1016/j.ecolind.2020.106259

Zhang YS, Wu DT, LyU X (2020c) A review on the impact of land use/land cover change on ecosystem services from a spatial scale perspective. J Nat Resour 35(5):1172-1189. https://doi.org/10.31497/zrzyxb.20200513

Zhang ZM, Gao JF, Gao YN (2015) The influences of land use changes on the value of ecosystem services in Chaohu Lake Basin, China. Environmental Earth Sciences 74:385-395. https://doi.org/10.1007/s12665-015-4045-z

Zheng SR (2016) Reflections on the Three Gorges Project sirnce Its Operation. Engineering 2:389-397. http://dx.doi.org/10.1016/J.ENG.2016.04.002

Zhou ZX, Li J, Zhang W (2016) Coupled urbanization and agricultural ecosystem services in GuanzhongTianshui Economic Zone. Environ Sci Pollut Res 23:15407-15417. https://doi.org/10.1007/s11356-016-6726-x 